\title{
IgG-blocking antibodies inhibit IgE-mediated anaphylaxis in vivo through both antigen interception and $\mathrm{F} c \gamma \mathrm{R} / \mathrm{lb}$ cross-linking
}

\author{
Richard T. Strait, 1,2 Suzanne C. Morris,, 3,4 and Fred D. Finkelman 3,5,6 \\ ${ }^{1}$ Division of Emergency Medicine, Cincinnati Children's Hospital Medical Center, Cincinnati, Ohio, USA. Department of Pediatrics, \\ Division of Emergency Medicine, and 3Department of Internal Medicine, Division of Immunology, University of Cincinnati College of Medicine, \\ Cincinnati, Ohio, USA. ${ }^{4}$ Research Service, Cincinnati Veterans Affairs Medical Center, Cincinnati, Ohio, USA. ${ }^{5}$ Division of Immunobiology, \\ University of Cincinnati College of Medicine, Cincinnati, Ohio, USA. ${ }^{6}$ Medicine Service, Cincinnati Veterans Affairs Medical Center, Cincinnati, Ohio, USA.
}

\begin{abstract}
Although it has long been hypothesized that allergen immunotherapy inhibits allergy, in part, by inducing production of IgG Abs that intercept allergens before they can cross-link mast cell FceRI-associated IgE, this blocking $\mathrm{Ab}$ hypothesis has never been tested in vivo. In addition, evidence that IgG-allergen interactions can induce anaphylaxis by activating macrophages through Fc $\gamma$ RIII suggested that IgG Ab might not be able to inhibit IgE-mediated anaphylaxis without inducing anaphylaxis through this alternative pathway. We have studied active and passive immunization models in mice to approach these issues and to determine whether any inhibition of anaphylaxis observed was a direct effect of allergen neutralization by IgG Ab or an indirect effect of cross-linking of $F c \varepsilon R I$ to the inhibitory IgG receptor $F c \gamma$ RIIb. We demonstrate that IgG $A b$ produced during the course of an immune response or administered passively can completely suppress IgE-mediated anaphylaxis; that these IgG blocking Abs inhibit IgE-mediated anaphylaxis without inducing Fc $\gamma$ RIII-mediated anaphylaxis only when IgG Ab concentration is high and challenge allergen dose is low; that allergen epitope density correlates inversely with the allergen dose required to induce both IgE- and Fc $\gamma$ RIII-mediated anaphylaxis; and that both allergen interception and Fc $\gamma$ RIIb-dependent inhibition contribute to in vivo blocking Ab activity.
\end{abstract}

\section{Introduction}

The rationale for allergen immunotherapy for atopic disorders has changed with time. Initially, "allergy vaccines" were thought to induce the production of IgG blocking antibody (BA), which might neutralize allergen molecules before they could interact with what were later discovered to be IgE Abs bound to FceRI on mast cells and basophils $(1,2)$. More recently, this BA concept has been supplemented by evidence that IgG Ab-allergen complexes may inhibit mast cell signaling by cross-linking the immunoreceptor tyrosine activation motif-containing activating receptor FceRI to the immunoreceptor tyrosine inhibition motif-containing inhibitory receptor Fc $\gamma$ RIIb (3), and that immunotherapy may instead inhibit allergy by immunomodulation: decreasing Th2 cytokine production, increasing Th1 cytokine production, and/or activating regulatory $T$ cells (4-7). Surprisingly, despite the long history of allergen immunotherapy, positive correlations between IgG Ab levels and protection against allergen-induced disease in some but not all studies (8-12), and in vitro experiments that demonstrated IgG Ab inhibition of antigen-induced (Ag-induced) mast cell/basophil degranulation and other IgE-mediated effects $(5,13,14)$, there has been no in vivo proof of the BA concept.

Nonstandard abbreviations used: Ag, antigen; Asm, antiserum; BA, blocking antibody; GIgG, goat IgG; $\alpha$ GIgG Asm, heat-inactivated mouse anti-GIgG antiserum; GaMD, goat anti-mouse IgD antiserum; IgE $\alpha$ TNP, IgE anti-TNP mAb; IgGaGIgG, IgG anti-GIgG; IgG $\alpha$ TNP, purified IgG fraction of $\alpha$ TNP Asm; IVCCA, in vivo cytokine capture assay; MMCP-1, mouse mast cell protease-1; NIP, 3-nitro-4-hydroxy5 -iodophenylacetyl; PAF, platelet-activating factor; TNP, trinitrophenyl; $\alpha$ TNP Asm, heat-inactivated mouse anti-TNP antiserum; TNP-G $\alpha$ MD, TNP conjugated to GaMD; TNP-OVA, TNP conjugated to OVA; TNP-OVA-NIP, NIP conjugated to TNP-OVA.

Conflict of interest: The authors have declared that no conflict of interest exists. Citation for this article: J. Clin. Invest. doi:10.1172/JCI25575
We initiated such in vivo studies because of unexpected results that were obtained in an animal model of anaphylaxis in which mice were immunized with a goat $\mathrm{Ab}$ against mouse $\operatorname{IgD}(\mathrm{G} \alpha \mathrm{MD}$, which stimulates large IgG1, IgE, IL-4, and mast cell responses and a small IgG2a response, but little or no IgG3 or IgG2b production [refs. 15-19 and F.D. Finkelman, unpublished data]) and challenged with $100 \mu$ g of the relevant Ag, goat IgG (GIgG) (20). Although GIgG challenge induced severe anaphylaxis, anaphylaxis was mediated by IgG, Fc $\gamma$ RIII, macrophages, and platelet-activating factor (PAF), rather than by IgE, FceRI, mast cells, and histamine (20). In view of the strong IgE, IL-4, and mast cell responses that develop in G $\alpha M D$-treated mice, it seemed unlikely that the failure of GIgG challenge to induce IgE-mediated anaphylaxis resulted from a lack of IgE or mast cells. Instead, the strong IgG anti-GIgG (IgG $\alpha \mathrm{GIgG}$ ) response that develops in these mice raised the possibility that IgG $\alpha$ GIgG blocked IgE-mediated anaphylaxis, either by intercepting GIgG before it could bind to IgE/FceRI on mast cells or by cross-linking FceRI to Fc $\gamma$ RIIb. We have now performed in vivo studies to evaluate these possibilities. Our results show that allergen-specific IgG can block IgE-mediated anaphylaxis in vivo; define conditions under which blocking occurs without inducing Fc $\gamma$ RIII-mediated anaphylaxis; and demonstrate the importance of both Ag interception and FcyRIIb-mediated inhibition as mechanisms of BA function.

\section{Results}

IgG BA inhibits IgE-mediated anaphylaxis in GaMD-immunized mice by intercepting Ag before it can cross-link mast cell-associated IgE. GaMD immunization induces marked increases in IgE and mastocytosis (ref. 17 and F.D. Finkelman, unpublished data). Despite this, challenging GaMD-immunized mice with $100 \mu \mathrm{g}$ of the relevant Ag, 


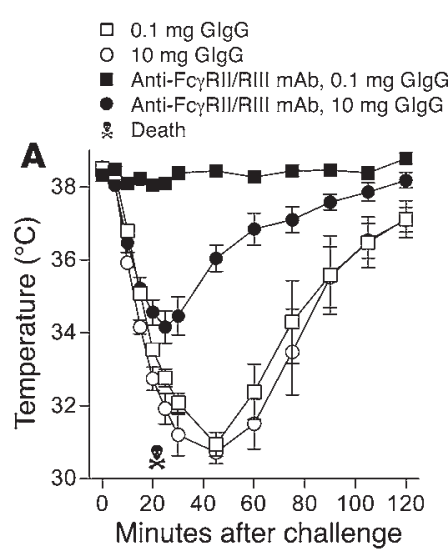

B

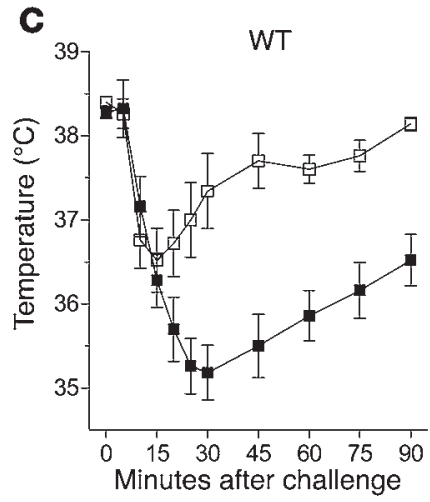

D

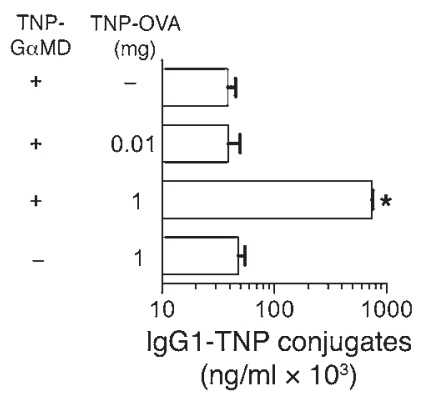

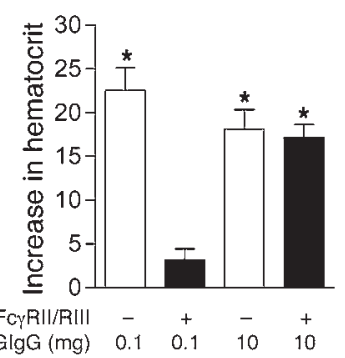

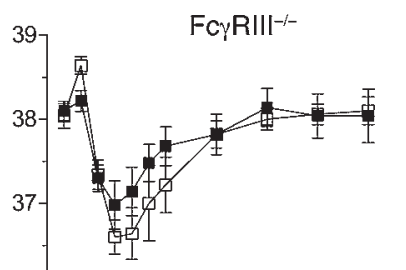

35

$\mathbf{E}$

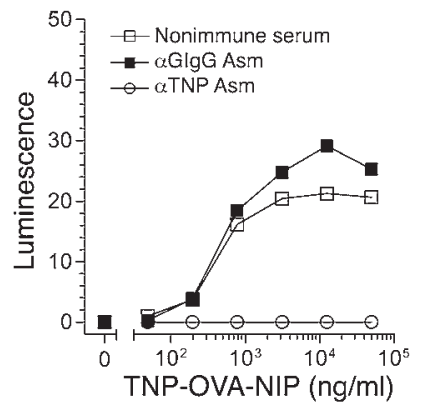

\section{Figure 1}

FcyRIII-independent anaphylaxis in GaMD-primed mice requires challenge with a high dose of $\mathrm{Ag}$. (A) BALB/c mice (5 per group) were primed s.c. with $\mathrm{G} \alpha \mathrm{MD}$, then challenged i.v. 14 days later with 0.1 or $10 \mathrm{mg}$ of GlgG. Some mice were pretreated 24 hours before GlgG challenge with $500 \mu \mathrm{g}$ of anti-Fc $\gamma R$ RI/RIII mAb to block IgG-mediated anaphylaxis. Rectal temperatures were followed for 2 hours after challenge. (B) Mice primed and challenged as in $\mathbf{A}$ had blood drawn before and 15 minutes after challenge. Hematocrit levels were determined. ${ }^{*} P<0.05$ compared with mice treated with anti-FcyRII/RIII mAb and challenged with $0.1 \mathrm{mg}$ of GlgG. (C) WT (left) and FcyRIII-deficient mice (right) were primed s.c. with $\mathrm{G} \alpha \mathrm{MD}$, then challenged i.v. 14 days later with $10 \mathrm{mg}$ of GlgG. Some mice were injected s.c. with $500 \mu \mathrm{g}$ of antiFcyRII/RIII mAb 24 hours before GIgG challenge. Rectal temperatures were followed for 90 minutes after challenge. (D) BALB/c mice were primed s.c. with TNP-G $\alpha$ MD or saline, then challenged 14 days later with $0,0.01$, or $1 \mathrm{mg}$ of biotinylated TNP-OVA. Blood was drawn 5 minutes later, and IgG1-TNP-OVA complexes in serum were quantitated by ELISA. ${ }^{*} P<0.05$ compared with other measured levels. (E) TNPOVA-NIP was diluted in nonimmune serum or heat-inactivated serum pooled from mice immunized 10-12 days earlier with GaMD ( $\alpha \mathrm{GlgG}$ Asm) or TNP-G $\alpha$ MD ( $\alpha$ TNP Asm). Binding of serum TNP-OVA-NIP by $\operatorname{lgE} \alpha$ TNP was measured by ELISA. Means \pm SEMs are shown for all data in this and subsequent figures unless otherwise indicated.

treated mice (Figure 1, A and B). Increasing the dose of challenge Ag should saturate BA and allow Ag to cross-link mast cell-associated FceRI but should not affect FcyRIIb-mediated inhibition of mast cell degranulation or competition between GIgG-specific and nonspecific IgE for mast cell FceRI. Thus, our observation supports the hypothesis that IgE-mediated anaphylaxis in GaMD-immunized mice is inhibited by $\operatorname{IgG~BA}$ interception of the challenge Ag.

These results did not eliminate the possibility that IgG BA suppresses IgE-mediated anaphylaxis in GaMD-immunized mice by both intercepting Ag and cross-linking FceRI to FcyRIIb. AntiFcyRII/RIII mAb blocks both the FcyRIII-dependent, macrophagedependent pathway of anaphylaxis and FcyRIIb-dependent inhibition of mast cell-mediated anaphylaxis, which makes it impossible to isolate FcyRIIb-dependent inhibition in WT mice. To isolate FcyRIIb inhibition, we compared the effects of anti-FcyRII/RIII $\mathrm{mAb}$ on anaphylaxis induced by high-dose $(10 \mathrm{mg}) \mathrm{Ag}$ challenge in GoMD-immunized WT and FcyRIII-deficient mice. Anti-FcyRII/ RIII mAb had its expected inhibitory effect on anaphylaxis in WT mice, but little, if any, inhibitory or stimulatory effect in FcyRIIIdeficient mice (Figure 1C). Thus, Ag interception, rather than the cross-linking of FceRI to FcyRIIb, accounts for most of the inhibition of IgE-mediated anaphylaxis in G $\alpha M D$-immunized mice.

If IgG BA in GaMD-immunized mice inhibits IgE-mediated anaphylaxis by intercepting $\mathrm{Ag}$, it should be possible to demonstrate IgG-Ag complexes in the blood of immunized, Ag-challenged mice and to directly show that serum IgG Ab blocks Ag binding to IgE. Experiments were performed to test each of these predictions. Because it is difficult to assay for the mouse IgG-GIgG complexes that should be formed in GaMD-immune mice challenged with GIgG, we instead used a system that takes advantage of the strong $\mathrm{Ab}$ response generated to molecules conjugated to GaMD but allows more sensitive and precise detection of the Ag-Ab complex. Mice primed with a conjugate of trinitrophenyl-GaMD (TNPGaMD) develop a large IgG1 anti-TNP Ab response (21). TNPOVA-mouse IgG complexes were easily detected in serum $5 \mathrm{~min}$ utes after TNP-G $\alpha \mathrm{MD}$-immunized mice were challenged with 1 $\mathrm{mg}$ of TNP-OVA (Figure 1D). 
A Presence of

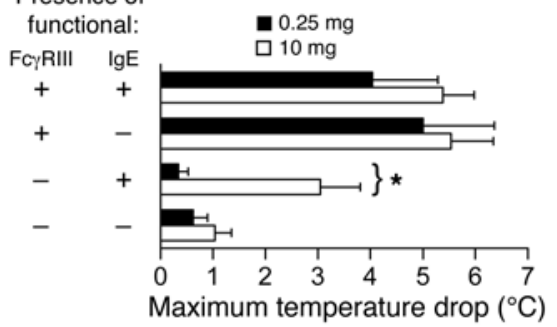

B

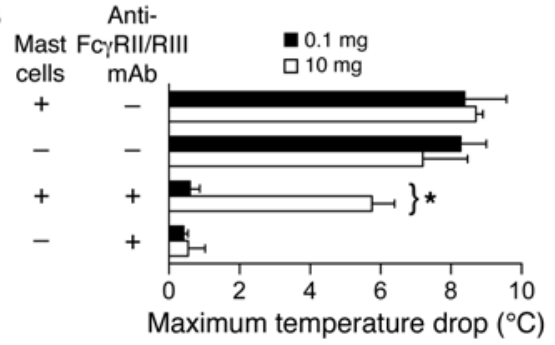

C

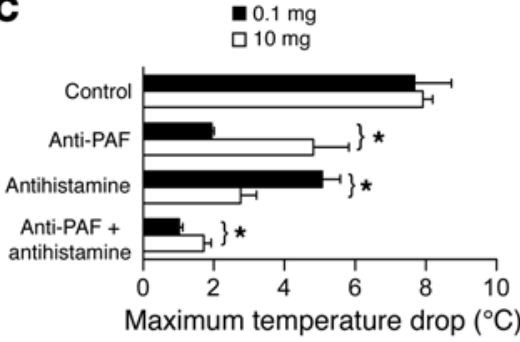

D

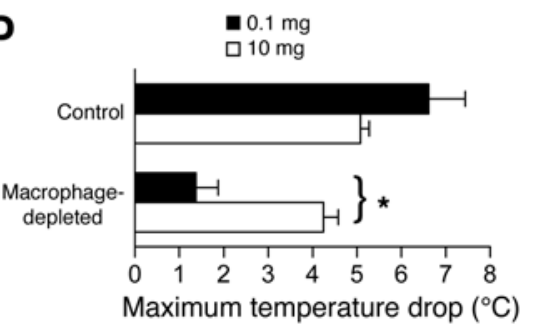

$\mathbf{E}$

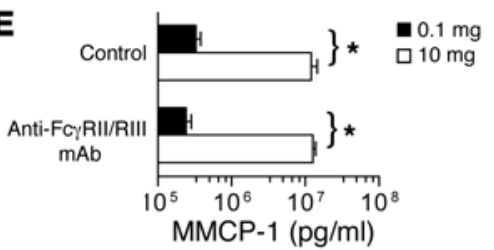

F
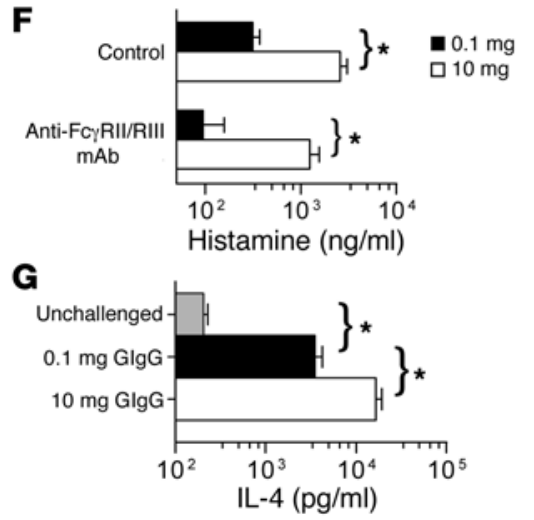

Figure 2

IgE/FceRI/mast cell-dependent anaphylaxis in GaMD-primed mice requires challenge with a high dose of Ag. Mice (4-5 per group) were primed s.c. with $0.2 \mathrm{ml}$ of $\mathrm{G} \alpha \mathrm{MD}$, then challenged i.v. 14 days later with GlgG. Temperature was followed for 2 hours after challenge, and the maximum temperature decrease was calculated. Mice were matched for genetic background in all experiments. (A) WT mice and mice deficient in Fc $\gamma$ RIII, $\mathrm{IgE}$, or both were challenged as shown. (B) WT (+) and mast cell-deficient W/Wv $(-)$ mice were treated as shown. (C) BALB/c mice were injected 15-30 minutes before challenge with $66 \mu \mathrm{g}$ of CV6209 (PAF antagonist), $0.2 \mathrm{mg}$ of both triprolidine and cimetidine (H1 and H2 antagonists), all 3 antagonists, or no antagonist and challenged as shown. (D) BALB/c mice were injected i.v. with $1 \mathrm{mg}$ of gadolinium (macrophage inhibitor) or saline 1 day before GlgG challenge. (E) BALB/c mice were injected s.c. with saline or $500 \mu \mathrm{g}$ of anti-Fc RII/RIII mAb 1 day before GlgG challenge. Blood was drawn 2 hours after GlgG challenge, and MMCP-1 levels were determined. (F) BALB/c mice were injected s.c. with saline or $500 \mu \mathrm{g}$ of anti-Fc $\gamma$ RII/RIII mAb 1 day before GlgG challenge. Anticoagulated blood was obtained for histamine measurement 5 minutes after challenge. (G) BALB/c mice were bled 4 hours after challenge with the indicated dose of GIgG, and IL-4 secretion was evaluated by in vivo cytokine capture assay (IVCCA) (51). ${ }^{*} P<0.05$.

To directly determine whether Ag immunization can inhibit Ag binding to IgE, we immunized mice with GaMD or TNP-G $\alpha$ MD and evaluated the ability of their serum to block TNP-OVA bind-

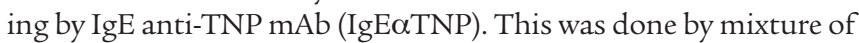
immune or nonimmune serum with a doubly haptenated Ag (TNPOVA-3-nitro-4-hydroxy-5-iodophenylacetyl [TNP-OVA-NIP]), capture of this Ag onto microtiter plate wells with anti-NIP mAb, and then determination of whether captured TNP-OVA-NIP could be bound by IgE $\alpha$ TNP. This assay detected IgE anti-TNP binding to as little as $2 \times 10^{2} \mathrm{ng}$ of TNP-OVA-NIP per milliliter in serum from nonimmune or GaMD-immune mice (which lack anti-TNP Ab) but did not detect IgE anti-TNP binding to the highest concentration of TNP-OVA tested $\left(5 \times 10^{4} \mathrm{ng} / \mathrm{ml}\right)$ in serum from TNPGaMD-immunized mice (Figure 1E). Thus, immune serum specifically inhibits IgE binding to Ag by a factor of more than 250 .

Characterization of anaphylaxis induced by low and high doses of challenge Ag in GaMD-immunized mice. To provide additional evidence that induction of IgE-mediated anaphylaxis in G $\alpha \mathrm{MD}$-immune mice requires high-dose Ag challenge, we characterized IgE, FcR, cell type, and mediator requirements for anaphylaxis in GaMDimmunized mice challenged with either low-dose (0.1-0.25 mg) or high-dose (10 mg) GIgG. FcyRIII-deficient, IgE-deficient, and FcyRIII/IgE-double-deficient mice were used to evaluate the importance of the IgG/FcyRIII and IgE/FceRI anaphylaxis pathways in these experiments. With low-dose Ag challenge, anaphylaxis was FcyRIII-dependent and IgE-independent, while high-dose challenge induced anaphylaxis through both pathways
(Figure 2A). Double-deficient mice failed to develop anaphylaxis when challenged with either a high or a low Ag dose. Consistent results were observed when neither anaphylaxis pathway was operative because Fc $\gamma$ RIII-deficient mice were pretreated with anti-IgE $\mathrm{mAb}$ to neutralize IgE and desensitize mast cells, or IgE-deficient mice were treated with the anti-FcyRI/RIII mAb to block Fc $\gamma$ RII/ RIII and desensitize macrophages (not shown). Studies with mast cell-deficient, $\mathrm{W} / \mathrm{W}^{\mathrm{v}}$ mice were also consistent. Although blocking Fc $\gamma$ RIII with anti-Fc $\gamma$ RII/RIII mAb abolished the anaphylactic response to low-dose, but not high-dose, Ag challenge in WT mice, anti-FcyRII/RIII mAb blocked this response to both low- and high-dose Ag challenge in $\mathrm{W} / \mathrm{W}^{\mathrm{v}}$ mice (Figure 2B). Furthermore, consistent with observations that Fc $\gamma$ RIII-mediated anaphylaxis is predominantly PAF-dependent while IgE-mediated anaphylaxis is predominantly histamine-dependent (20), responses to low-dose Ag challenge were inhibited more by a PAF antagonist than by antihistamine, while the opposite sensitivity to mediator antagonists was seen for high-dose Ag challenge (Figure 2C). Similarly, gadolinium, which inhibits macrophage, but not mast cell, function (22-24), suppressed the response to low-dose, but not high-dose, Ag challenge (Figure 2D). Finally, studies performed to directly evaluate IgE-mediated mast cell activation revealed 50 -fold higher serum levels of mouse mast cell protease-1 (MMCP-1) and 10-fold higher serum levels of histamine (both markers of mast cell degranulation) in mice challenged with highrather than low-dose $\mathrm{Ag}$ (Figure 2, $\mathrm{E}$ and $\mathrm{F}$ ), and these responses were not substantially inhibited by anti-FcrRII/RIII mAb. In con- 

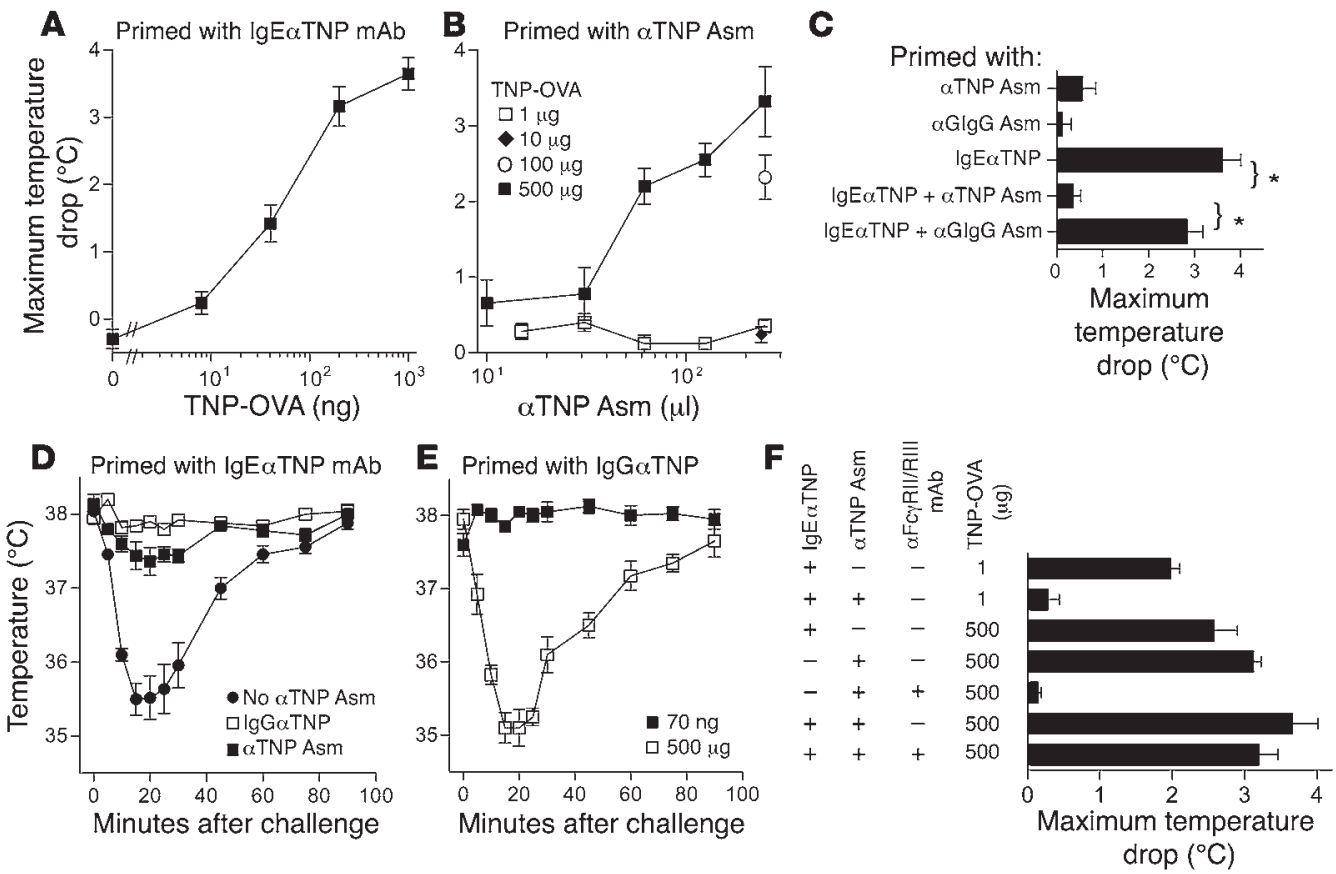

Figure 3

Identification of the serum factor that blocks IgE-mediated anaphylaxis as Ag-specific IgG. (A) BALB/c mice (5 per group) were primed with 10 ug of IgE $\alpha$ TNP i.v., then challenged i.v. 24 hours later with the doses of TNP-OVA shown on the abscissa. Maximum temperature decreases during the 90 minutes after challenge were calculated for this and all subsequent panels. (B) BALB/c mice (5 per group) were primed i.v. with the doses of $\alpha$ TNP Asm shown on the abscissa and challenged i.v. 24 hours later with the indicated doses of TNP-OVA. (C) BALB/c mice (5 per group) were primed i.v. with $10 \mu \mathrm{g}$ of IgE $\alpha \mathrm{TNP}, 250 \mu \mathrm{l}$ of $\alpha \mathrm{GlgG}$ Asm, and/or $250 \mu \mathrm{l}$ of $\alpha \mathrm{TNP}$ Asm as indicated, and challenged i.v. 24 hours later with $1 \mu \mathrm{g}$ of TNP-OVA. * $P<0.05$. (D) BALB/c mice (5 per group) were primed i.v. with $10 \mu \mathrm{g}$ of IgE $\alpha$ TNP plus saline, $250 \mu \mathrm{l}$ of IgGaTNP, or $125 \mu$ l of $\alpha$ TNP Asm, then challenged i.v. 24 hours later with $70 \mathrm{ng}$ of TNP-OVA. (E) BALB/c mice (5 per group) were primed i.v. with $250 \mu \mathrm{l}$ of IgGaTNP, then challenged i.v. 24 hours later with $70 \mathrm{ng}$ or $500 \mu \mathrm{g}$ of TNP-OVA. (F) BALB/c mice (5 per group) were primed i.v. with either $10 \mu \mathrm{g}$ of $\operatorname{lgE} \alpha$ TNP or $250 \mu \mathrm{l}$ of $\alpha$ TNP Asm or both and treated with saline or $500 \mu \mathrm{g}$ of anti-Fc $\gamma$ RII/RIII mAb. Mice were challenged i.v. 24 hours later with 1 or $500 \mu \mathrm{g}$ of TNP-OVA.

trast, large IL-4 responses were generated in response to even lowdose Ag challenge, although high-dose challenge further increased the response approximately 6-fold (Figure 2G). Ag-induced IL-4 responses in this system are generated predominantly by basophils in response to IgE cross-linking and are approximately 10 -fold more sensitive than mast cell MMCP-1 and histamine responses to IgE cross-linking (25). Taken together, these observations demonstrate that the IgG/FcrRIII/macrophage/PAF pathway of anaphylaxis is induced at least as strongly by low-dose as by high-dose Ag in G $\alpha \mathrm{MD}$-immunized mice, while high-dose Ag challenge is required to induce the $\operatorname{IgE} / \mathrm{Fc \varepsilon R} / \mathrm{mast}$ cell/histamine pathway in these mice.

IgE-dependent anaphylaxis is induced by very low doses of $A g$ in the absence of BA but is inbibited by Ag-specific IgG BA. The greater quantity of Ag required to induce IgE-mediated than to induce Fc $\gamma$ RIII-mediated anaphylaxis in GaMD-immunized mice might reflect IgG BA interception of Ag, as we have hypothesized. However, experiments with actively immunized mice did not rule out an alternative possibility: more Ag might be required to activate mast cells, even in the absence of BA, than to activate macrophages. Nor could active immunization experiments directly determine whether immune serum contains a factor that inhibits IgE-mediated anaphylaxis induced by low-dose Ag challenge, whether this putative inhibitory factor is Ag-specific, or whether it is an IgG Ab. Investigation of each issue required studies in which IgE-dependent anaphylaxis could be studied in the absence of IgG BA and concentrations of $\operatorname{IgE}$ and $\operatorname{IgG}$ Abs could be precisely defined and flexibly adjusted. To develop such a system, mice were primed with IgE $\alpha$ TNP and challenged 1 day later with TNP-OVA. In contrast to the more than $250-\mu \mathrm{g}$ dose of Ag required to induce IgE-mediated anaphylaxis in the G $\alpha M D$ system, anaphylaxis in IgE $\alpha$ TNP-primed mice was induced by as little as $10 \mathrm{ng}$ of TNP-OVA, and a plateau in severity was approached at approximately $1 \mu \mathrm{g}$ (Figure $3 \mathrm{~A})$. When mice were instead primed with heat-inactivated mouse anti-TNP antiserum ( $\alpha$ TNP Asm), which contains IgG but not IgE antibodies to TNP, more than $10 \mu \mathrm{g}$ of TNP-OVA was required to induce anaphylaxis, and anaphylaxis was more severe in mice challenged with $500 \mu \mathrm{g}$ of TNP-OVA than in mice challenged with $100 \mu \mathrm{g}$ (Figure 3B). Mice primed with either IgE $\alpha$ TNP or $\alpha$ TNP Asm did not respond to i.v. OVA that was not TNP-conjugated (data not shown). The approximately 1,000-fold difference in the doses of $\mathrm{Ag}$ required to induce anaphylaxis in mice primed with IgE $\alpha$ TNP versus $\alpha$ TNP Asm suggested that $\alpha$ TNP Asm might be able to block anaphylaxis in IgE $\alpha$ TNP-primed mice without inducing IgG-mediated anaphylaxis, if the dose of challenge Ag were less than that required to induce anaphylaxis by the Fc $\gamma$ RIII-dependent pathway.

To test this possibility, unprimed or IgE $\alpha$ TNP-primed mice were injected with saline, $\alpha$ TNP Asm, or, as a control, heat-inactivated mouse anti-GIgG antiserum ( $\alpha$ GIgG Asm; produced by mice immunized with GaMD), then challenged with $1 \mu \mathrm{g}$ of TNP-OVA. 

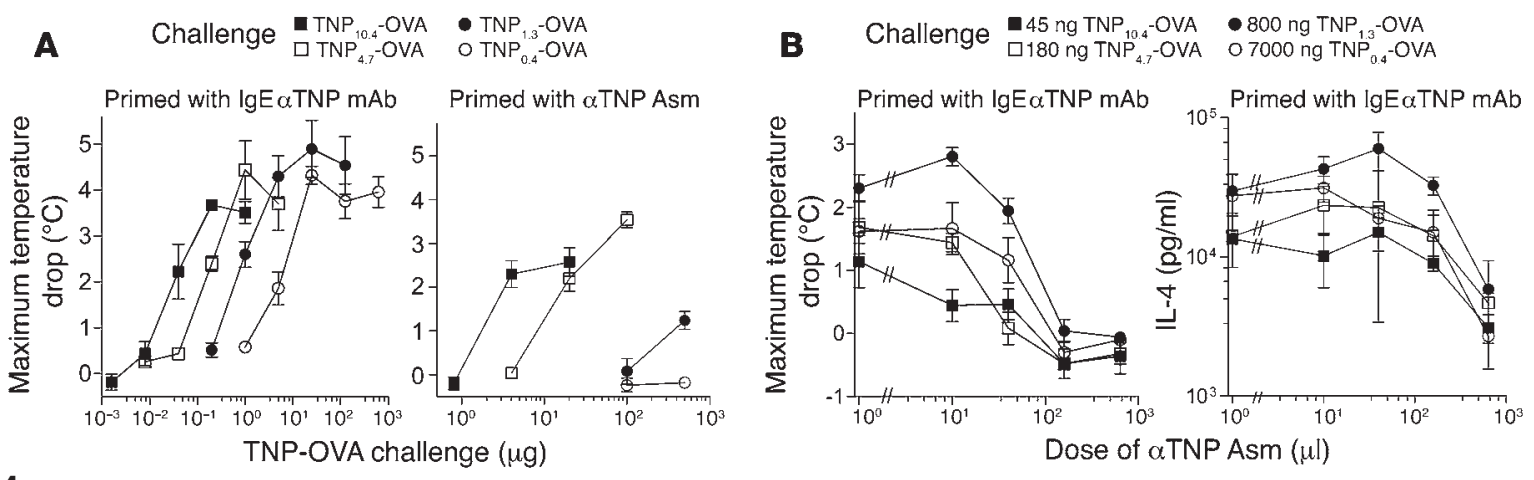

\section{Figure 4}

Effects of Ag epitope density on IgE- and FcyRIII-mediated anaphylaxis and IgG BA inhibition of IgE-mediated anaphylaxis. (A) BALB/c mice (5 per group) were primed i.v. with either $10 \mu \mathrm{g}$ of IgE $\alpha$ TNP (left) or $40 \mu \mathrm{l}$ of $\alpha$ TNP Asm (right), then challenged i.v. 24 hours later with TNP-OVA. Doses of TNP-OVA conjugates are indicated on graph abscissas; molar TNP/OVA ratios of the different conjugates tested are indicated in the figure. Maximum temperature decreases during the 90 minutes after challenge were determined. (B) BALB/c mice (5 per group) were primed i.v. with 10 $\mu \mathrm{g}$ of $\lg \mathrm{E} \alpha \mathrm{TNP}$ and injected i.v. with the quantities of $\alpha \mathrm{TNP}$ Asm indicated on the graph abscissas. Mice were injected i.v. 24 hours later with $10 \mu \mathrm{g}$ of biotin-anti-IL-4 mAb and challenged i.v. with the indicated doses of the TNP-OVA conjugates. Maximum temperature decreases during the 90 minutes after challenge were determined (left). Blood was drawn 2 hours after challenge, and IL-4 secretion was evaluated by IVCCA (right) (51).

Significant hypothermia developed in mice that initially received IgE $\alpha$ TNP with or without $\alpha$ GIgG Asm but did not develop in mice that initially received both IgE $\alpha$ TNP and $\alpha$ TNP Asm (Figure 3C). Thus, a constituent of serum from TNP-G $\alpha$ MD-immunized, but not GaMD-immunized, mice can block IgE-mediated anaphylaxis in vivo without mediating FcyRIII-dependent anaphylaxis when mice are challenged with a relatively low dose of $\mathrm{Ag}$.

To demonstrate that IgG is the TNP-G $\alpha$ MD immune serum constituent that blocks IgE-mediated anaphylaxis, we purified the IgG fraction of $\alpha$ TNP Asm (IgG $\alpha$ TNP) from this serum and tested its ability to block IgE-mediated anaphylaxis. Concentrations of the $\alpha \mathrm{TNP}$ Asm and its IgG fraction were adjusted to similar anti-TNP $\mathrm{Ab}$ titers, as determined by ELISA (not shown). Anaphylaxis was inhibited by the IgG fraction at least as well as by the unfractionated antiserum (Figure 3D). To determine whether IgG $\alpha$ TNP Ab could also mediate anaphylaxis, presumably through the FcyRIIIdependent mechanism, in mice challenged with a higher dose of $\mathrm{Ag}$, mice primed with purified IgG $\alpha \mathrm{TNP}$ were challenged with 70 ng or $500 \mu \mathrm{g}$ of TNP-OVA. Anaphylaxis developed in mice challenged with the high, but not the low, TNP-OVA dose (Figure 3E). Finally, to prove the Fc $\gamma$ RIII-dependence of anaphylaxis in mice primed with $\alpha$ TNP Asm and challenged with Ag and demonstrate the ability of high-dose Ag to overcome IgG blocking of IgE-mediated anaphylaxis, as in our active anaphylaxis model, we primed mice with IgE $\alpha$ TNP, $\alpha$ TNP Asm, or both, blocked Fc $\gamma$ RIII-mediated anaphylaxis with anti-Fc $\gamma$ RII/RIII $m A b$ in some mice, and challenged mice with 1 or $500 \mu \mathrm{g}$ of TNP-OVA. IgE-dependent anaphylaxis was induced by challenge with $1 \mu \mathrm{g}$ of TNP-OVA in mice primed only with IgE $\alpha$ TNP but blocked in mice that also received $\alpha$ TNP Asm. This blocking was overcome when the dose of challenge Ag was increased to $500 \mu \mathrm{g}$ (Figure 3F). The 500- $\mathrm{gg}$ dose of Ag also induced Fc $\gamma$ RIII-mediated anaphylaxis (it induced anaphylaxis in mice pretreated with only $\alpha$ TNP Asm but not in mice pretreated with both $\alpha$ TNP Asm and anti-Fc $\gamma$ RII/RIII mAb). Taken together, these results demonstrate that (a) IgE-dependent anaphylaxis requires less Ag than Fcy RIII-dependent anaphylaxis in the absence of IgG BA; (b) Ag-specific IgG BA increases the dose of $\mathrm{Ag}$ required to induce IgE-mediated anaphylaxis and, if the $\mathrm{Ag}$ dose is sufficiently high, allows the development of Fc $\gamma$ RIII-depen- dent anaphylaxis; and (c) the inhibitory effect of IgG BA on IgEmediated anaphylaxis can be overcome by an increase in the dose of challenge Ag. These results are consistent with observations in our active immunization anaphylaxis model, in which the high concentrations of mouse IgG $\alpha$ GIgG induced by GaMD immunization support FcyRIII-mediated anaphylaxis when mice are challenged with $100 \mu \mathrm{g}$ of GIgG but block IgE-mediated anaphylaxis unless the dose of challenge Ag is increased substantially.

Influence of Ag epitope density on the inbibition of anaphylaxis by blocking $A b$. Our conclusions about BA function were drawn from studies in which anti-TNP Ab-primed mice were challenged with a TNP-OVA preparation that averaged 10.4 TNP moieties per OVA molecule (TNP $_{10.4}$-OVA). Because not all allergens have so many identical determinants (epitopes) on a single Ag molecule and high epitope density should increase the ability of an allergen to cross-link IgE/ FceRI on mast cells and make it more difficult to block IgE/FceRI cross-linking with an IgG BA, we investigated the influence of Ag epitope density on IgE- and FcyRIII-mediated anaphylaxis and on IgG BA inhibition of IgE-mediated anaphylaxis (Figure 4). As expected, the quantity of TNP-OVA required to induce anaphylaxis in mice primed with a fixed dose of IgE $\alpha$ TNP or $\alpha$ TNP Asm increased as the molar TNP/OVA ratio decreased, although the increase was less marked for IgE-mediated anaphylaxis than for IgG-mediated anaphylaxis (Figure 4A, left and right panels, respectively).

To determine whether the quantity of $\alpha$ TNP Asm required to inhibit IgE-mediated anaphylaxis or IgE-mediated basophil IL-4 production is affected by challenge Ag epitope density, mice were primed with $10 \mu \mathrm{g}$ of IgE $\alpha \mathrm{TNP}$, then challenged with doses of $\mathrm{TNP}_{10.4}$-OVA, $\mathrm{TNP}_{4.7}$-OVA, $\mathrm{TNP}_{1.3}$-OVA, or $\mathrm{TNP}_{0.4}$-OVA that induce similar degrees of mast cell-dependent hypothermia and basophil-dependent IL-4 production but are too low to induce Fc $\gamma$ RIII-dependent anaphylaxis. Results of these studies demonstrate that the quantity of $\alpha$ TNP Asm required to block hypothermia and IL-4 production is relatively constant when differences in challenge Ag epitope density are compensated for by adjustment of challenge Ag dose and that more $\alpha$ TNP Asm is required to inhibit IL-4 production than to block the development of hypothermia (Figure 4B). Because the amount of IgG Ab required to block IgE/FceRI-mediated anaphylaxis is not affected by decreas- 

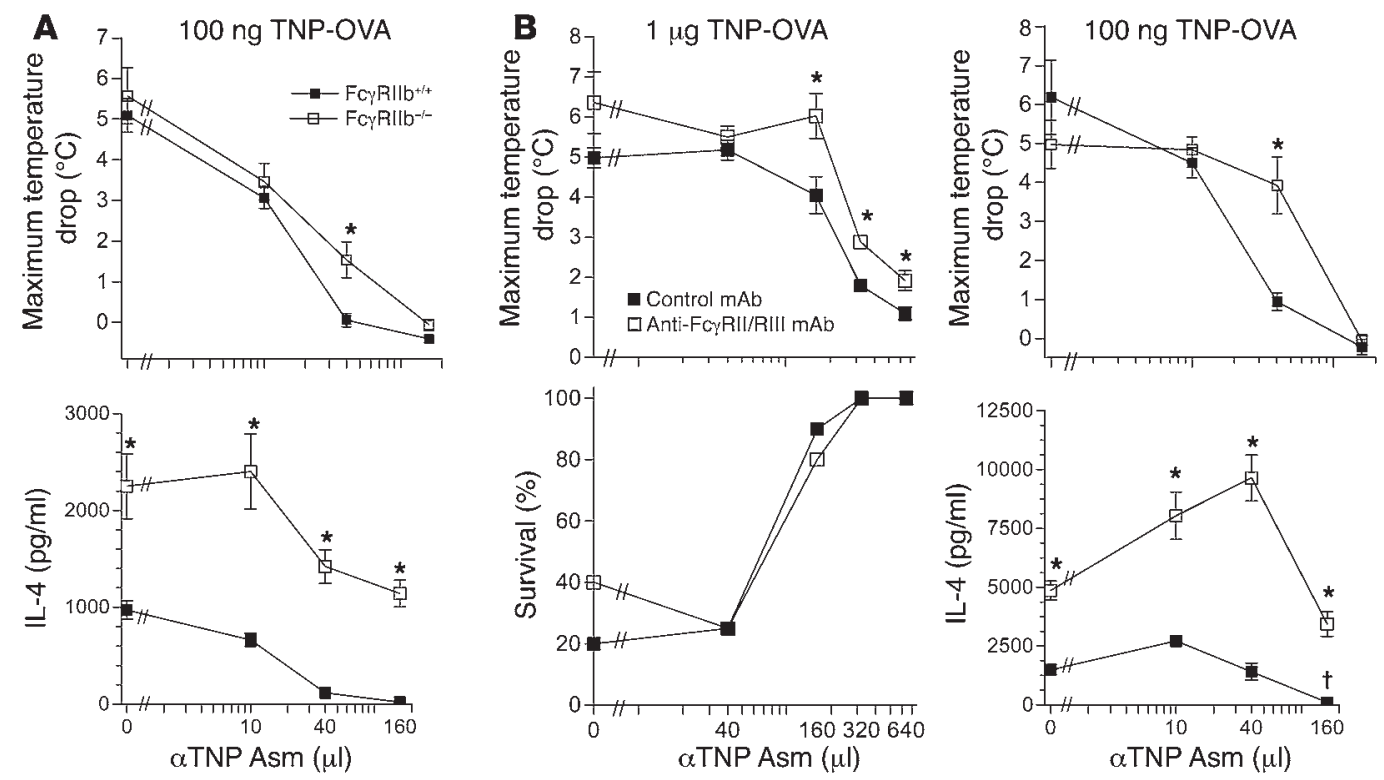

Figure 5

IgG BA inhibits IgE-mediated anaphylaxis through both FcyRllb-dependent and -independent mechanisms. (A) WT and FcyRllb-deficient mice (8-10 per group) were primed i.v. with $10 \mu \mathrm{g}$ of IgE $\alpha \mathrm{TNP}$ and treated i.v. with the quantities of $\alpha$ TNP Asm indicated on the graph abscissas. Mice were injected i.v. 24 hours later with $10 \mu \mathrm{g}$ of biotin-anti-IL-4 mAb and challenged i.v. with 100 ng of TNP-OVA. Maximum temperature decreases during the 90 minutes after challenge were determined. Blood was drawn 2 hours after challenge, and IL-4 secretion was determined by IVCCA. All mice survived. (B) FcyRIII-deficient mice (5 per group) were primed i.v. with $10 \mu \mathrm{g}$ of IgE $\alpha$ TNP and treated i.v. with the quantities of $\alpha$ TNP Asm indicated on the graph abscissas and s.c. with $500 \mu \mathrm{g}$ of either anti-FcyRII/RIII mAb or isotype-matched control mAb. Mice were injected i.v. 24 hours later with $10 \mu \mathrm{g}$ of biotin-anti-IL-4 mAb and challenged i.v. with $1 \mu \mathrm{g}$ or $100 \mathrm{ng}$ of TNP-OVA. Maximum temperature decreases during the 90 minutes after challenge were determined. Survival was $100 \%$ for all mice challenged with 100 ng of TNP-OVA and as indicated for mice challenged with $1 \mu \mathrm{g}$ of TNP-OVA. Blood was drawn 2 hours after challenge, and IL-4 secretions were determined by IVCCA for mice challenged with $100 \mathrm{ng}$ TNP-OVA. ${ }^{*} P<0.05$. ${ }^{\dagger} P<0.05$ compared with control mAb-treated mice that received no $\alpha$ TNP Asm.

es in Ag epitope density that are compensated for by increases in Ag dose while decreases in Ag epitope density increase the Ag dose required to induce IgG/FcrRIII-mediated anaphylaxis more than the dose required to induce IgE/FceRI-mediated anaphylaxis, the ability of IgG Ab to block IgE/FceRI-mediated anaphylaxis without permitting Fc $\gamma$ RIII-mediated anaphylaxis increases as Ag epitope density decreases.

IgG BA inhibits anaphylaxis by 2 mechanisms. Our active anaphylaxis studies suggested that IgG BA suppresses IgE-mediated anaphylaxis by Ag interception rather than by cross-linking FceRI to FcyRIIb. It remained possible, however, that Ag interception and FceRI-Fc $\gamma$ RIIb cross-linking are redundant inhibitory mechanisms. If so, the inhibitory effect of FceRI-FcyRIIb cross-linking might only become apparent when concentrations of IgG BA are limiting. To evaluate this possibility, we compared the ability of $\alpha$ TNP Asm to (a) inhibit IgE-mediated anaphylaxis and IgE induction of basophil IL-4 secretion in WT versus Fc $\gamma$ RIIb-deficient mice (Figure 5A) and (b) inhibit the same phenomena in FcyRIIIdeficient mice that had been treated with anti-FcyRII/RIII mAb, to selectively block Fc $\gamma$ RIIb signaling, or with an isotype-matched control $\mathrm{mAb}$ (Figure 5B). Inhibition of Fc $\gamma \mathrm{RIIb}$ signaling did not affect IgE-mediated anaphylaxis but substantially decreased the basophil IL- 4 response, in the absence of $\alpha$ TNP Asm, in both sets of experiments. Addition of $\alpha$ TNP Asm inhibited IgE-mediated anaphylaxis and basophil IL-4 secretion in all experiments, even when FcyRIIb was absent or blocked. However, 2- to 4-fold more $\alpha$ TNP Asm was required to suppress IgE-mediated anaphylaxis, and more than 4 -fold more $\alpha$ TNP Asm was required to suppress basophil IL-4 secretion to the same extent in mice in which FcyRIIb was absent or blocked as in mice in which FcyRIIb was present and functional. Thus, IgG BA inhibits IgE-mediated anaphylaxis by both intercepting Ag molecules and cross-linking FceRI to Fc $\gamma$ RIIb. FceRI-Fc $\gamma$ RIIb cross-linking is not required to inhibit IgE-mediated anaphylaxis or IL-4 production when IgG $\mathrm{BA}$ is present in excess, but it amplifies the inhibitory effect of limiting concentrations of IgG BA.

\section{Discussion}

Our studies provide direct in vivo evidence that allergen-specific IgG BA can protect against IgE-mediated immunopathology. This evidence was obtained in 2 in vivo systems: a relatively natural model (active immunization) and a model that is more artificial but also more precise and flexible (passive immunization). Priming in the active immunization model was achieved by immunization with G $\alpha M D$, which induces large GIgG-specific IgE and IgG responses $(15,16)$. Using this model, $\operatorname{IgE} / \mathrm{Fc \varepsilon R} /$ mast cell-mediated anaphylaxis could only be induced by a high dose of Ag, while a lower Ag dose could induce IgG/Fc $\gamma \mathrm{RIII} / \mathrm{macrophage-depen-}$ dent anaphylaxis. This combination of a large $\operatorname{IgG}$ response to immunization and the need for high-dose Ag challenge to induce IgE-mediated anaphylaxis suggested that the IgG was intercepting challenge Ag before it could reach the IgE. This possibility was supported by direct evidence that IgG Abs in serum form complexes with injected $\mathrm{Ag}$ and inhibit $\mathrm{Ag}$ binding to IgE.

This interpretation was confirmed in a system in which Ab transfer was used both to prime mice for IgE-mediated anaphylaxis 
and to inhibit IgE-mediated anaphylaxis. Studies with this passive transfer system demonstrated that IgE-mediated anaphylaxis can be inhibited by transfer of purified Ag-specific IgG Ab. This transfer system also allowed differentiation of Ag dose requirements for IgE- versus IgG-mediated anaphylaxis and definition of the circumstances in which IgG Ab can protect against IgE-mediated anaphylaxis without inducing anaphylaxis through the IgG/ $\mathrm{Fc} \gamma \mathrm{RIII} / \mathrm{macrophage} \mathrm{pathway.} \mathrm{The} \mathrm{most} \mathrm{critical} \mathrm{differentiating} \mathrm{fac-}$ tor for the induction of IgE- versus IgG-mediated anaphylaxis was the amount of challenge Ag. In the absence of IgG BA, IgE-mediated anaphylaxis could be induced by less than $50 \mathrm{ng}$ of TNP-OVA, while induction of IgG-mediated anaphylaxis required more than $1 \mu \mathrm{g}$ of the same Ag. In contrast, in the presence of BA, the quantity of Ag required to trigger IgE-mediated anaphylaxis increased substantially, until considerably more Ag was required to induce IgE-mediated anaphylaxis than IgG/Fc $\gamma$ RIII-mediated anaphylaxis, as seen in our active anaphylaxis system. Thus, IgG BA has a purely protective effect when the quantity of challenge Ag is less than that required to trigger IgG-mediated anaphylaxis. This protective effect is lost, however, as the amount of challenge Ag dose is increased. This results both from insufficient interception of challenge Ag before it can cross-link IgE/FceRI on mast cells and from the generation of enough Ag-IgG Ab complexes to activate Fc $\gamma$ RIII-dependent mediator production by macrophages. Thus, IgG BA should be more protective in people challenged with a low dose of allergen (for example, an insect sting) than in people challenged with a high dose of allergen (for example, infusion of an antibiotic).

IgE-mediated anaphylaxis in mice primed with IgE $\alpha$ TNP and challenged with TNP-OVA was suppressed when mice were also injected with heat-inactivated serum pooled from mice immunized with TNP-G $\alpha M D$, which contained IgG anti-TNP and IgG anti-GIgG Ab, but not when mice were injected with heat-inactivated serum pooled from G $\alpha$ MD-immunized mice, which contained anti-GIgG but not anti-TNP Ab. Therefore, IgG inhibition of IgE-mediated anaphylaxis is Ag-specific.

Transfer of IgE and IgG Ab allowed comparison of the effects of varying the epitope density of the challenge Ag on IgE- versus IgG-mediated anaphylaxis and on the consequent ability of IgG Ab to protect against IgE-mediated anaphylaxis without mediating Fc $\gamma$ RIII-dependent anaphylaxis. Increasing the hapten density of TNP-OVA reduced the quantity of TNP-OVA required to induce IgG-mediated anaphylaxis more than it reduced the quantity of TNP-OVA required to induce IgE-mediated anaphylaxis, and, as a result, decreased the relative ability of IgG Ab to inhibit IgE-mediated anaphylaxis without inducing Fcy RIII-dependent anaphylaxis. These observations suggest that immune complexes that contain several IgG molecules may be required to efficiently cross-link Fc $\gamma$ RIII (a low-affinity receptor) and activate macrophages, while more limited cross-linking of mast cell FceRI by a high-affinity interaction between $\mathrm{Ag}$ and FceRI-associated IgE can efficiently induce mast cell degranulation.

Finally, studies with both active and passive immunization models defined and quantitated the importance of FceRI-FcyRIIb interactions in BA inhibition of anaphylaxis. Interactions between the stimulatory and inhibitory receptors were not required for BA suppression of IgE-mediated anaphylaxis: suppression was seen in both the active and the passive anaphylaxis models in FcyRIIbdeficient mice and in WT and FcrRIII-deficient mice in which Fc $\gamma$ RIIb function was blocked by anti-Fc $\gamma$ RII/RIII mAb. Furthermore, IgE-mediated anaphylaxis, in the absence of BA, did not dif- fer in severity between WT and Fc $\gamma$ RIIb-deficient mice or between anti-Fc $\mathrm{RII} / \mathrm{RIII} \mathrm{mAb}$-treated and control mAb-treated Fc $\gamma$ RIIIdeficient mice. This suggests that a direct IgE-Fc $\gamma$ RIIb interaction did not inhibit IgE-mediated anaphylaxis in our model, although such inhibition has been observed in another study (26). However, our data suggest inhibition of IgE-mediated basophil IL-4 production by an IgE-Fc $\gamma$ RIIb interaction: IgE-mediated IL-4 responses were 2- to 3-fold higher in FcyRIIb-deficient mice than in WT mice, and in WT mice treated with anti-FcyRI/RIII $m A b$ than in WT mice treated with a control $\mathrm{mAb}$. Furthermore, experiments in our passive anaphylaxis model confirmed the previously reported importance of IgG-Fc $\gamma$ RIIb interactions in the regulation of anaphylaxis $(26,27)$. Two- to 4 -fold more IgG BA was required to inhibit IgE-mediated anaphylaxis in Fc $\gamma$ RIIb-deficient mice than in WT mice, and in anti-Fc $\gamma$ RII/RIII mAb-treated Fc $\gamma$ RIII-deficient mice than in mice of the same strain that were treated with a control mAb. Thus, IgG BA inhibits IgE-mediated anaphylaxis through 2 mechanisms: it intercepts Ag before it can cross-link mast cell FceRI-associated IgE, and it cross-links FceRI to FcyRIIb. FceRI-Fc $\gamma$ RIIb cross-linking appears to contribute importantly to BA function when BA levels are limiting but is redundant when BA concentrations are high relative to concentrations of Ag. Our demonstration that FceRI-Fc $\gamma$ RIIb cross-linking can suppress IgEdependent anaphylaxis is consistent with evidence that IgG-IgE Fc fusion proteins suppress mast cell degranulation $(28,29)$.

Because IgG BA may be present in limiting amounts in allergy patients who have received immunotherapy, the inhibitory effect of cross-linking FceRI to Fc $\gamma$ RIIb is likely to have an important role in controlling IgE-mediated anaphylaxis. As a result, the efficacy of immunotherapy may be affected by Fc $\gamma$ RIIb polymorphisms: $\mathrm{BA}$ and immunotherapy that induces BA production may most effectively suppress IgE-mediated anaphylaxis in people who have allelic forms of the Fc $\gamma \mathrm{RIIb}$ gene that are associated with the most potent inhibitory Fc $\gamma$ RIIb function $(30,31)$.

Two reservations must be considered about the relevance of our predictions to human disease and therapy. First, Fc $\gamma$ RIII-mediated anaphylaxis, as demonstrated in our mouse model, has never been demonstrated in humans. This may result from the difficulty of detecting this phenomenon rather than from its absence. Because humans, like mice, have macrophages that express FcyRIII and that can be induced by IgG-Ag complexes to secrete inflammatory mediators (32), there is no a priori reason to believe that mice and humans differ in this regard. More likely, the quantities of allergenspecific IgG Ab and allergen that are required to induce FcyRIIIdependent anaphylaxis may rarely be achieved in humans. The occurrence of Ag-mediated anaphylaxis in the absence of detectable IgE specific for the relevant Ag (33), however, suggests that IgG-mediated anaphylaxis may be a human, as well as a mouse, phenomenon. Furthermore, more aggressive allergen immunization, made possible by blocking of IgE-mediated anaphylaxis with a human IgG anti-IgE mAb (34) and potentially with other chimeric proteins $(28,35)$, may raise quantities of allergen-specific IgG $\mathrm{Ab}$ to the level required to induce IgG-mediated anaphylaxis.

Secondly, it is not clear that IgG blocking of IgE-mediated anaphylaxis, which we demonstrated in a model in which mice are challenged i.v. with allergen, will occur when allergen challenge occurs through mucosal routes. Because IgG levels are low in the gastrointestinal tract and mast cells that can bind allergen-specific IgE are located in intestinal villi, it seems doubtful that IgG Abs inhibit the induction of intestinal mast cell degranulation by 
ingested allergens. Results of preliminary studies, however, support the possibility that other isotypes, such as IgA, inhibit IgEmediated mucosal allergy: lower doses of $\mathrm{Ag}$ are required to induce $\mathrm{IgE} /$ mast cell-mediated allergic diarrhea in J chain-deficient mice, which have approximately $10 \%$ of normal intestinal IgA levels, than in WT mice of the same background strain (R.T. Strait et al., unpublished data). It is also possible that ingested Ags only induce systemic anaphylaxis if they are absorbed from the gut and bind to mast cells associated with the circulation. If so, IgG BA would be expected to have a major role in limiting systemic anaphylaxis even when $\mathrm{Ag}$ is ingested. Consequently, it seems likely that immunotherapy suppresses anaphylactic and other IgE-mediated allergic disorders, including allergic disorders that predominantly affect mucosal organs, by inducing BA, as well as through distinct mechanisms that decrease IgE secretion, suppress Th2 responses, and stimulate Th1 and regulatory $\mathrm{T}$ cell responses (36-42).

\section{Methods}

Mice. BALB/c mice were purchased from the National Cancer Institute. Mast cell-deficient WBB6F1-Kit $t^{\mathbb{W}} / K_{i t}^{W-v}\left(\mathrm{~W} / \mathrm{W}^{v}\right)$ mice and (WBB6F1-Kit ${ }^{\mathbb{W}} / K^{2} t^{W-v} \times$ WBB6F1 $\left.{ }^{+/}\right) \mathrm{F}_{1}(\mathrm{~W} /+)$ mice (which have a normal phenotype) (43) along with Fc $\gamma$ RIIb-deficient (27) and C57BL/6 FcyRIIb-sufficient mice were purchased from Jackson Laboratory. IgE-deficient mice (44) were a gift from Phillip Leder (Harvard University, Cambridge, Massachusetts, USA), and FcyRIIIdeficient mice (26) were a gift from Jeffrey Ravetch (Rockefeller University, New York, New York, USA). All experimental procedures were performed with approval from the Institutional Animal Care and Use Committees of the Cincinnati Children's Hospital Research Foundation and the Department of Veterans Affairs Medical Center (Cincinnati, Ohio, USA).

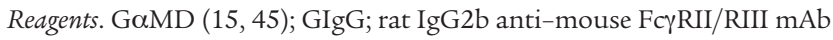
(24G2) (46) from ATCC; rat IgG2b anti-4-hydroxy-3-nitrophenylacetyl mAb (J1.2), a gift from John Abrams (DNAX Research Inc., Palo Alto, California, USA); rat IgG2a anti-mouse IgE mAb (EM-95) (47), a gift from Zelig Eshhar (Weizmann Institute, Rehovot, Israel); and mouse IgE $\alpha$ TNP (IGEL 2a) (48) from ATCC were prepared as described $(20,49)$. TNP-labeled GaMD was prepared by mixture of $20 \mathrm{ml}$ of GaMD in $1 \mathrm{ml}$ of $0.1 \mathrm{M} \mathrm{NaHCO}_{3}$ buffer, pH 9.6, with 25 mg of TNP-succinyl-Osu (Biosearch Technologies Inc.) dissolved in $1 \mathrm{ml}$ of DMSO and incubation of the mixture overnight at room temperature. The incubated solution was dialyzed against 5 changes of 0.15 $\mathrm{M} \mathrm{NaCl} / 0.01 \mathrm{M} \mathrm{NaHCO}_{3}, \mathrm{pH}$ 8.0. TNP-OVA was similarly produced by mixture of $50 \mathrm{mg}$ of OVA in $5 \mathrm{ml}$ of bicarbonate buffer with serial 4-fold dilutions of TNP-succinyl-Osu (starting concentration, $25 \mathrm{mg} / \mathrm{ml}$ ) in DMSO. TNP-OVA-NIP was produced by mixture of NIP-succinyl-Osu (Biosearch Technologies Inc.) with $\mathrm{TNP}_{0.4}$-OVA at a $1: 2$ weight ratio in DMSO and dialyzing as above. TNP-OVA was biotinylated with E-Z Link sulfo-NHSbiotin (Pierce) at a 10:1 weight ratio in DMSO. $\alpha$ TNP Asm was produced by injection of BALB/c mice i.p. with $0.2 \mathrm{ml}$ of TNP-G $\alpha$ MD. Mice were bled 10-12 days after immunization, and sera were pooled. The pooled serum was heated to $56^{\circ} \mathrm{C}$ for 30 minutes to inactivate complement and IgE. The IgG fraction of $\alpha \mathrm{TNP}$ Asm was purified by ammonium sulfate fractionation (25-50\% saturated cut) followed by DEAE-cellulose (DE-52; Whatman International Ltd.) ion exchange chromatography. Fractions were tested for the presence of mouse IgG1 and non-Ig proteins by gel double diffusion, and appropriate fractions were pooled. The PAF antagonist CV6209 was purchased from BIOMOL. The $\mathrm{H} 1$ receptor antagonist triprolidine and the macrophage inhibitor gadolinium were purchased from Sigma-Aldrich. $\mathrm{T}$ he $\mathrm{H} 2$ receptor antagonist cimetidine was purchased from Tocris. Abs for measurement of in vivo IL-4 secretion were obtained from BD.

Measurement of $I L-4$, bistamine, and MMCP-1. Mice were injected with biotinylated anti-IL-4 mAb (BVD4-1D11) (50) at the time of TNP-OVA challenge. Serum was collected 2 hours later, and IL-4 was measured by in vivo cytokine capture assay (IVCCA) (51). Blood drawn 5 minutes after Ag challenge and placed immediately on ice had histamine content measured by ELISA with a kit purchased from IBL. Serum levels of MMCP-1 were measured in blood drawn 2 hours after Ag challenge with an ELISA kit purchased from Moredun.

ELISAs. IgG1 anti-TNP activity was quantitated with ELISA plate wells coated with $\mathrm{TNP}_{10.4}$-OVA and blocked with SuperBlock (Pierce). Serial dilutions of sera and serum fractions were added to wells, followed sequentially by affinity-purified rabbit anti-mouse $\gamma 1 \mathrm{Ab}(15)$, alkaline phosphataselabeled goat anti-rabbit $\mathrm{Ab}(15)$, and Tris-based buffer with $p$-nitrophenyl phosphate substrate (Calbiochem). IgG1-TNP-OVA-biotin complexes in mouse serum were captured onto ELISA plate wells coated with streptavidin and were detected with rabbit anti-mouse IgG1 Ab (Zymed Laboratories Inc.), followed by alkaline phosphatase-labeled goat anti-rabbit $\operatorname{Ig}(15)$ and substrate ( $p$-nitrophenyl phosphate; Calbiochem). The ability of IgE $\alpha$ TNP to bind to TNP in the presence of IgG anti-TNP was determined by addition of serum containing TNP-OVA-NIP with or without IgG anti-TNP Ab to ELISA plate wells coated with J1.2, a rat IgG2b anti-4-hydroxy-3-nitrophenylacetyl $\mathrm{mAb}$ that cross-reacts with NIP, and then addition of biotin-labeled IgE $\alpha$ TNP, followed by HRP-streptavidin and SuperSignal ELISA substrate (Pierce Biotechnology). ELISA plates were read for absorbance with a Multiskan MCC/340 ELISA reader (Thermo Electron Corp.) or for luminescence with a Fluoroskan Ascent FL reader (Thermo Electron Corp.).

Active anaphylaxis model. Mice (5 per group except where noted otherwise) were primed with $0.2 \mathrm{ml} \mathrm{G \alpha MD}$ or TNP-G $\alpha M D$ s.c., then challenged 14 days later i.v. with GIgG or TNP-OVA. All experiments were repeated at least once.

Passive anaphylaxis model. Mice were primed i.v. with different combinations of $10 \mu \mathrm{g}$ of IgE $\alpha \mathrm{TNP}$ and variable amounts of $\alpha \mathrm{GIgG}$ Asm, $\alpha \mathrm{TNP}$ Asm, or IgGaGIgG, then challenged i.v. 24 hours later with TNP-OVA or OVA.

Anaphylaxis. The severity of the anaphylactic shock was assessed by change in temperature, activity level, and/or hematocrit, as previously described $(20,52)$.

Treatment with inbibitors. Fc $\gamma \mathrm{RIIb} / \mathrm{RIII}$, histamine, PAF, and macrophage function was inhibited as described $(20,53)$.

Evaluation of TNP/OVA molar ratio. The absorbance of TNP-OVA conjugates was measured at wavelengths of 280 and $340 \mu \mathrm{M}$ with a Spectronic GENESYS Spectrophotometer (Spectronic Instruments), and TNP/OVA molar ratio was determined as described (54).

Statistics. Differences in temperature, hematocrit, and concentrations of histamine, MMCP-1, and IL-4 between groups of mice were compared using the Mann-Whitney $t$ test (GraphPad Prism 4.0; GraphPad software). A $P$ value less than 0.05 was considered significant.

\section{Acknowledgments}

This work was supported by NIH/National Institute of Allergy and Infectious Diseases grant K08 AI50006 (to R.T. Strait), a Veterans Affairs Merit Award (to F.D. Finkelman), a grant from the Food Allergy and Anaphylaxis Network, and a grant from the Asthma and Allergy Foundation of America (to R.T. Strait). The authors thank Steve Dennis, Cathy Griffith, and Lucy Voegele for their technical assistance.

Received for publication May 6, 2005, and accepted in revised form January 3, 2006.

Address correspondence to: Fred D. Finkelman, Division of Immunology, University of Cincinnati, College of Medicine, 231 Albert Sabin Way, Cincinnati, Ohio 45267-0563, USA. Phone: (513) 5584701; Fax: (513) 558-3799; E-mail: ffinkelman@pol.net. 
1. Flicker, S., and Valenta, R. 2003. Renaissance of the blocking antibody concept in type I allergy. Int Arch. Allergy Immunol. 132:13-24.

2. Galli, S., and Lantz, C. 1999. Allergy. In Fundamen tal immunology. W.E. Paul, editor. Lippincott-Raven. Philadelphia, Pennsylvania, USA. 1127-1174.

3. Daeron, M., Malbec, O., Latour, S., Arock, M., and Fridman, W.H. 1995. Regulation of high-affinity $\mathrm{IgE}$ receptor-mediated mast cell activation by murine low-affinity IgG receptors. J. Clin. Invest. 95:577-585.

4. Sade, K., Kivity, S., Levy, A., and Fireman, E. 2003. The effect of specific immunotherapy on T-cell receptor repertoire in patients with allergy to house-dust mite. Allergy. 58:430-434.

5. van Neerven, R.J., et al. 1999. Blocking antibodies induced by specific allergy vaccination prevent the activation of CD4+ $\mathrm{T}$ cells by inhibiting serumIgE-facilitated allergen presentation. J. Immunol. 163:2944-2952.

6. Durham, S.R., and Till, S.J. 1998. Immunologic changes associated with allergen immunotherapy. J. Allergy Clin. Immunol. 102:157-164.

7. Francis, J.N., Till, S.J., and Durham, S.R. 2003. Induction of $\mathrm{IL}-10^{+} \mathrm{CD} 4{ }^{+} \mathrm{CD} 25^{+} \mathrm{T}$ cells by grass pollen immunotherapy. J. Allergy Clin. Immunol. 111:1255-1261.

8. Golden, D.B., et al. 1982. Clinical relevance of the venom-specific immunoglobulin $\mathrm{G}$ antibody level during immunotherapy. J. Allergy Clin. Immunol. 69:489-493.

9. Urbanek, R., Krauss, U., Ziupa, J., and Smedegard, G. 1983. Venom-specific IgE and IgG antibodies as a measure of the degree of protection in insectsting-sensitive patients. Clin. Allergy. 13:229-234.

10. Kemeny, D.M., et al. 1989. IgG and IgE antibodies after immunotherapy with bee and wasp venom. Int. Arch. Allergy Appl. Immunol. 88:247-249.

11. Golden, D.B., et al. 1992. Clinical correlation of the venom-specific IgG antibody level during maintenance venom immunotherapy. J. Allergy Clin. Immu nol. 90:386-393.

12. Ewan, P.W., Deighton, J., Wilson, A.B., and Lachmann, P.J. 1993. Venom-specific IgG antibodies in bee and wasp allergy: lack of correlation with protection from stings. Clin. Exp. Allergy. 23:647-660.

13. Garcia, B.E., Sanz, M.L., Gato, J.J., Fernandez, J., and Oehling, A. 1993. IgG4 blocking effect on the release of antigen-specific histamine. J. Investig. Allergol. Clin. Immunol. 3:26-33.

14. Nouri-Aria, K.T., et al. 2004. Grass pollen immunotherapy induces mucosal and peripheral IL-10 responses and blocking IgG activity. J. Immunol. 172:3252-3259.

15. Finkelman, F.D., et al. 1982. Polyclonal activation of the murine immune system by an antibody to IgD. II. Generation of polyclonal antibody production and cells with surface IgG. J. Immunol. 129:638-646.

16. Champion, B.R., Buckham, S., Page, K., Obray, H., and Zanders, E.D. 1991. Secondary immunoglobulin responses of BALB/c mice previously stimulated with goat anti-mouse IgD. Immunology. 72:336-343

17. Finkelman, F.D., Snapper, C.M., Mountz, J.D., and Katona, I.M. 1987. Polyclonal activation of the murine immune system by a goat antibody to mouse IgD. IX. Induction of a polyclonal IgE response. J. Immunol. 138:2826-2830.

18. Svetic, A., et al. 1991. Cytokine gene expression after in vivo primary immunization with goat antibody to mouse IgD antibody. J. Immunol. 147:2391-2397.
19. Mountz, J.D., Smith, J., Snapper, C.M., Mushinski, J.F., and Finkelman, F.D. 1987. Polyclonal activation of the murine immune system by an antibody to IgD. VIII. Stimulation of IgD secretion. J. Immunol. 139:2172-2178.

20. Strait, R.T., Morris, S.C., Yang, M., Qu, X.W., and Finkelman, F.D. 2002. Pathways of anaphylaxis in the mouse. J. Allergy Clin. Immunol. 109:658-668.

21. Lees, A., et al. 1990. Rapid stimulation of large specific antibody responses with conjugates of antigen and anti-IgD antibody. J. Immunol. 145:3594-3600.

22. Singh, B., and de la Concha-Bermejillo, A. 1998. Gadolinium chloride removes pulmonary intravascular macrophages and curtails the degree of ovine lentivirus-induced lymphoid interstitial pneumonia. Int. J. Exp. Pathol. 79:151-162.

23. Rai, R.M., Zhang, J.X., Clemens, M.G., and Diehl, A.M. 1996. Gadolinium chloride alters the acinar distribution of phagocytosis and balance between pro- and anti-inflammatory cytokines. Shock. 6:243-247.

24. Lazar, G., Jr., et al. 1994. Inhibition of anaphylactic shock by gadolinium chloride-induced Kupffer cell blockade. Agents Actions. 41:C97-C98.

25. Khodoun, M.V., Orekhova, T., Potter, C., Morris, S., and Finkelman, F.D. 2004. Basophils initiate IL-4 production during a memory T-dependent response. J. Exp. Med. 200:857-870.

26. Ujike, A., et al. 1999. Modulation of immunoglobulin (Ig)E-mediated systemic anaphylaxis by low-affinity Fc receptors for IgG. J. Exp. Med. 189:1573-1579.

27. Takai, T., Ono, M., Hikida, M., Ohmori, H., and Ravetch, J.V. 1996. Augmented humoral and anaphylactic responses in Fc $\gamma$ RII-deficient mice. Nature. 379:346-349.

28. Zhang, K., et al. 2004. Inhibition of allergen-specific IgE reactivity by a human Ig Fc $\gamma$-Fce bifunctional fusion protein. J. Allergy Clin. Immunol. 114:321-327.

29. Saxon, A., Zhu, D., Zhang, K., Allen, L.C., and Kepley, C.L. 2004. Genetically engineered negative signaling molecules in the immunomodulation of allergic diseases. Curr. Opin. Allergy Clin. Immunol. 4:563-568.

30. Su, K., et al. 2004. A promoter haplotype of the immunoreceptor tyrosine-based inhibitory motifbearing Fc $\gamma$ RIIb alters receptor expression and associates with autoimmunity. II. Differential binding of GATA 4 and Yin-Yang 1 transcription factors and correlated receptor expression and function. J. Immunol. 172:7192-7199.

31. Li, X., et al. 2003. A novel polymorphism in the Fc $\gamma$ RIIB (CD32B) transmembrane region alters receptor signaling. Arthritis Rheum. 48:3242-3252.

32. Finkelman, F.D., Rothenberg, M.E., Brandt, E.B., Morris, S.C., and Strait, R.T. 2005. Molecular mechanisms of anaphylaxis: lessons from studies with murine models [review]. J. Allergy Clin. Immunol. 115:449-457; quiz 458.

33. Galli, S.J. 2005. Pathogenesis and management of anaphylaxis: current status and future challenges. J. Allergy Clin. Immunol. 115:571-574.

34. Poole, J.A., Matangkasombut, P., and Rosenwasser, L.J. 2005. Targeting the IgE molecule in allergic and asthmatic diseases: review of the IgE molecule and clinical efficacy [review]. J. Allergy Clin. Immunol. 115(Suppl. 3):S376-S385.

35. Zhu, D., et al. 2005. A chimeric human-cat fusion protein blocks cat-induced allergy. Nat. Med. 11:446-449.

36. Ali, F.R., Kay, A.B., and Larche, M. 2002. The potential of peptide immunotherapy in allergy and asth- ma. Curr. Allergy Asthma Rep. 2:151-158.

37. Fellrath, J.M., et al. 2003. Allergen-specific T-cell tolerance induction with allergen-derived long synthetic peptides: results of a phase I trial. J. Allergy Clin. Immunol. 111:854-861.

38. Kemeny, D.M., MacKenzie-Mills, M., Harries, M.G., Youlten, L.J., and Lessof, M.H. 1983. Antibodies to purified bee venom proteins and peptides. II. A detailed study of changes in IgE and IgG antibodies to individual bee venom antigens. J. Allergy Clin. Immunol. 72:376-385.

39. Svenson, M., et al. 2003. Vaccination for birch pollen allergy. Induction of affinity-matured or blocking IgG antibodies does not account for the reduced binding of $\operatorname{IgE}$ to Bet v 1. Mol. Immunol. 39:603-612.

40. Tazaki, T., et al. 2004. Allergen rush immunotherapy increases interleukin (IL)-12 production and IL- $12 R \beta_{2}$ chain expression in patients with allergic asthma. Cell. Immunol. 228:20-26.

41. Ippoliti, F., et al. 2003. Immunomodulation during sublingual therapy in allergic children. Pediatr. Allergy Immunol. 14:216-221.

42. Wachholz, P.A., et al. 2002. Grass pollen immunotherapy for hayfever is associated with increases in local nasal but not peripheral Th1:Th2 cytokine ratios. Immunology. 105:56-62.

43. Kitamura, Y., Go, S., and Hatanaka, K. 1978. Decrease of mast cells in W/Wv mice and their increase by bone marrow transplantation. Blood. 52:447-452.

44. Oettgen, H.C., et al. 1994. Active anaphylaxis in IgE-deficient mice. Nature. 370:367-370.

45. Finkelman, F.D., Scher, I., Mond, J.J., Kung, J.T., and Metcalf, E.S. 1982. Polyclonal activation of the murine immune system by an antibody to IgD. I. Increase in cell size and DNA synthesis. J. Immunol. 129:629-637.

46. Unkeless, J.C. 1979. Characterization of a monoclonal antibody directed against mouse macrophage and lymphocyte Fc receptors. J. Exp. Med. 150:580-596.

47. Baniyash, M., and Eshhar, Z. 1984. Inhibition of IgE binding to mast cells and basophils by monoclonal antibodies to murine IgE. Eur. J. Immunol. 14:799-807.

48. Rudolph, A.K., Burrows, P.D., and Wabl, M.R. 1981 Thirteen hybridomas secreting hapten-specific immunoglobulin E from mice with Iga or Igb heavy chain haplotype. Eur. J. Immunol. 11:527-529.

49. Finkelman, F.D., Kessler, S.W., Mushinski, J.F., and Potter, M. 1981. IgD-secreting murine plasmacytomas: identification and partial characterization of two IgD myeloma proteins. J. Immunol. 126:680-687.

50. Finkelman, F.D., et al. 1993. Anti-cytokine antibodies as carrier proteins. Prolongation of in vivo effects of exogenous cytokines by injection of cytokine-anti-cytokine antibody complexes. J. Immunol. 151:1235-1244.

51. Finkelman, F.D., and Morris, S.C. 1999. Development of an assay to measure in vivo cytokine production in the mouse. Int. Immunol. 11:1811-1818.

52. Strait, R.T., Morris, S.C., Smiley, K., Urban, J.F., Jr., and Finkelman, F.D. 2003. IL-4 exacerbates anaphylaxis. J. Immunol. 170:3835-3842.

53. Mizgerd, J.P., Molina, R.M., Stearns, R.C., Brain, J.D., and Warner, A.E. 1996. Gadolinium induces macrophage apoptosis. J. Leukoc. Biol. 59:189-195.

54. Mischell, B., and Shiigi, S. 1980. Selected methods in cellular immunology. Freeman. San Francisco, California, USA. 346-349. 